ORIGINAL ARTICLE

\title{
The effect plyometric training with active-passive recovery for 8 weeks on performance physical abilities male judo athletes
}

\author{
Candra Kurniawan ${ }^{1 \mathrm{ABCDE}}$, Hari Setijono ${ }^{2 \mathrm{ABCDE}}$, Taufiq Hidayah ${ }^{3 \mathrm{BDE}}$, Hadi Hadi ${ }^{3 \mathrm{BCDE}}$, Sugiharto Sugiharto ${ }^{3 \mathrm{BCD}}$ \\ ${ }^{1}$ Postgraduate State University of Semarang, Indonesia \\ ${ }^{2}$ Department of Sport Science, State University of Surabaya, Indonesia \\ ${ }^{3}$ Department of Sport Science, State University of Semarang, Indonesia
}

Authors' Contribution: A - Study design; B - Data collection; C - Statistical analysis; D - Manuscript Preparation; E - Funds Collection.

\begin{tabular}{|c|c|}
\hline & \\
\hline $\begin{array}{l}\text { Background } \\
\text { and Study Aim }\end{array}$ & $\begin{array}{l}\text { Judo is a popular sport with dynamic characteristics and requires high physical abilities to achieve } \\
\text { achievement. The purpose of this study was to analyze the effects of plyometric exercises with active- } \\
\text { passive recovery for eight weeks to improve the physical ability of male judo athletes. }\end{array}$ \\
\hline $\begin{array}{l}\text { Material and } \\
\text { Methods }\end{array}$ & $\begin{array}{l}\text { This study used an experimental method. A total of } 36 \text { male judoka participated as samples and were } \\
\text { randomly divided into three groups. The plyometric experimental group with active recovery }(21.8 \pm 1.78 \\
\text { years, } 1.70 \pm 0.06 \mathrm{~m}, 71.1 \pm 13.5 \mathrm{~kg}) \text {, plyometric experimental group with passive recovery }(21.7 \pm 2.53 \text { years, } \\
1.71 \pm 0.06 \mathrm{~m}, 63.8 \pm 10.1 \mathrm{~kg}) \text {, and the control group }(21.4 \pm 2.30 \text { years, } 1.72 \pm 0.05 \mathrm{~m}, 67.4 \pm 7.76 \mathrm{~kg}) \text {. The training } \\
\text { program was conducted for eight weeks with a frequency of } 3 \text { times/week. The experimental group was } \\
\text { treated with plyometric training after warm-up, judo training, and post-exercise active-passive recovery } \\
\text { intervention. The control group continued regular judo training. The statistical analysis procedure used } \\
\text { the ANOVA test to determine the difference and comparison of the pre-test and post-test mean values in } \\
\text { the control and experimental groups with a significance level }(\mathrm{p}<0.05) \text {. }\end{array}$ \\
\hline Results & $\begin{array}{l}\text { The results showed differences in the average value of experimental and control groups found significant } \\
\text { to the } \mathrm{VO}_{2} \mathrm{Max} \text { endurance and leg power. Meanwhile, no significant difference occurred in left and right } \\
\text { grip strength, flexibility, and speed. }\end{array}$ \\
\hline Conc & $\begin{array}{l}\text { The study concluded that plyometric training with active-passive recovery positively affects male judoka's } \\
\mathrm{VO}_{2} \text { max endurance and leg power. } \\
\text { plyometric training program, active-passive recovery, performance physical ability }\end{array}$ \\
\hline
\end{tabular}

\section{Introduction}

Judo is a martial art sport that originated in Japan. Judo is one of Indonesia's most popular martial arts sports because it competed in various single-event and multievent national championship competitions. To get the best achievement or maximum points in a judo match. A judoka must have optimal physical performance resulting from the training process [1]. Periodization of the training program is a strategic step in training process to maintain and control the condition of athletes during training, as well as maximize athlete performance during matches [2]. One component of the martial arts training program is applying appropriate stress levels to optimize adaptation (improvement) and developing various physical qualities of athletes for competition preparation [3]. Thus, the given training program must focus on the load to be given [4], and athletes achieve maximum physical ability because training aims to improve performance based on morphological and functional adaptations [5].

The characteristics of the sport of judo are dynamic and require good physical strength [6]. When practicing or competing, judo athletes need much randori, uchikomi, slamming, and ground techniques to defend and attack opponents [7, 8]. Judo sport characteristics require

\footnotetext{
(c) Candra Kurniawan, Hari Setijono, Taufiq Hidayah, Hadi Hadi,

Sugiharto Sugiharto, 2021

doi:10.15561/26649837.2021.0604
}

strength, speed, flexibility, power, VO2Max endurance, and anaerobic also plays an essential role as an energy system to support Judoka performance [9, 10]. In addition, in judo training, there will be an increase in heart rate (HR) which causes instability in body condition. This, of course, requires a proper recovery process and is needed to accelerate the decrease in heart rate after exercise [11]. T.O. Bompa and Buzzichelli [12] explained, their ability to recovery influences about $50 \%$ of athletes' best performance.

Recovery is a process that is directly related to the training load used [13]. Trainers must understand the needs, determine effective recovery methods [14], to restore lost energy, and repair damaged muscle tissue systems after exercising [15]. The impact resulting from proper recovery after exercise will increase physical quality; an athlete needs a good recovery process to return his physical condition to its original state [16]. It is still challenging to find an appropriate recovery method that incorporates plyometric training in judo training from previous plyometric training. As stated by Yamagishi [17] that, it is essential to determine recovery methods in the form of active and passive appropriate post-exercise to facilitate maximum achievement, prevent neuromuscular disorders, and plyometric training has been shown to increase the anaerobic power output of athletes [18, 19].

This experimental study aims to analyze the effect 
of plyometric training with active-passive recovery on judoka physical abilities. The involvement of judoka in the scope of study aspect distinguishes it from other studies related to plyometric training with active-passive recovery. This study also aims to provide information and input on the effective use of plyometric training with active-passive recovery to obtain top judoka physical ability performance.

\section{Material and Methods \\ Participants}

A total of 36 experienced male judoka participating in the provincial level training camp voluntarily participated as a sample in the study. Samples were grouped randomly and divided into three groups, including 11 judoka plyometric experimental groups with active recovery $(21.8 \pm 1.78$ years, $1.70 \pm 0.06 \mathrm{~m}, 71.1 \pm 13.5 \mathrm{~kg}), 11$ judoka plyometric experimental groups with passive recovery $(21.7 \pm 2.53$ years, $1.71 \pm 0.06 \mathrm{~m}, 63.8 \pm 10.1 \mathrm{~kg})$, and 11 judokas in the control group $(21.4 \pm 2.30$ years, $1.72 \pm 0.05$ $\mathrm{m}, 67.4 \pm 7.76 \mathrm{~kg}$ ).

\section{Design and Procedure}

This research is an experimental study with a quasiexperimental approach design [20]. This study was previously confirmed through ethical stage clearance on the health research ethics commission institution State University of Semarang. To avoid data bias in the study, collecting research data was carried out before and after giving treatment for eight weeks. Data collection instruments were carried out in the form of tests and measurements, including anthropometric measurements (height and weight), VO2Max endurance (multistage fitness test), hand-grip strength (hand-grip dynamometer), body flexibility (sit and reach test), speed (30-meter speed test), and leg power (force plate test) [21,22]. The following describes the procedure for the treatment protocol in the study:

\section{Training Protocol}

The judo training program was applied to the three groups for eight weeks (3 days/week). In each training session, the experimental group and the control group were trained for 90 minutes. After warming up for 1520 minutes, the experimental group was given plyometric training before practicing judo in 15 variations of upper and lower plyometric movements. Meanwhile, the control group immediately did regular judo exercises. Furthermore, after the training, the experimental group was given active and passive recovery interventions for 10-20 minutes. The active recovery method aims to restore energy and gradually reduce muscle fatigue while still activating muscle performance to accelerate blood circulation back to normal. While the passive recovery method given aims to restore energy to its original state with complete or total rest. This is to reduce the effects of muscle fatigue, reduce lactate after exercise and return to homeostasis.

\section{Statistical Analysis}

They were testing statistical data of this study using ANOVA test on IBM SPSS V.25 and Microsoft Excel software licensed. The purpose of using the ANOVA test was to compare the average value of each group before and after being given treatment and test the difference in the post-test mean value between the experiment group and control group with the criteria for a testing significance level of $\mathrm{p}<0.05$.

\section{Results}

A good training program will affect the output of changes in the athlete's physical ability performance. At baseline measurement, there was no significant difference between any of the physical characteristic variables Table 1. Thus, it provided an acceptable homogeneity among the groups.

Comparing pre-test and post-test parameters Table 2. The plyometric experimental group with active recovery and plyometric experimental group with passive recovery resulted in a significant effect comparison $(\mathrm{p}<0.05)$ on increasing VO2Max endurance, left-hand grip strength, right-hand grip strength, flexibility, speed, and leg power. In the control group, the comparison of significant effect $(p<0.05)$ was on the strength of the right-hand grip, while the comparison of insignificant effect $(p>0.05)$ was on VO2Max endurance, left-hand grip strength, flexibility, speed, and leg power.

Furthermore, according to parameter difference test post-test results of Table 3. Experimental and control groups showed that the experimental group with active recovery plyometric, plyometric with passive recovery, and a control group make a significant effect $(p<0.05)$ on endurance VO2Max and leg power. While the differences

Table 1. Information on The Characteristics of Participants in Each Group (Mean \pm SD)

\begin{tabular}{|c|c|c|c|}
\hline Variable & $\begin{array}{l}\text { Experiment plyometric with } \\
\text { active recovery }(n=11)\end{array}$ & $\begin{array}{l}\text { Experiment plyometric } \\
\text { with passive recovery } \\
(n=11)\end{array}$ & Control Group $(n=11)$ \\
\hline & Mean \pm SD & Mean \pm SD & Mean \pm SD \\
\hline Age (year) & $21.8 \pm 1.78$ & $21.7 \pm 2.53$ & $21.4 \pm 2.30$ \\
\hline Height (m) & $1.70 \pm 0.06$ & $1.71 \pm 0.06$ & $1.72 \pm 0.05$ \\
\hline Weight (kg) & $71.1 \pm 13.5$ & $63.8 \pm 10.1$ & $67.4 \pm 7.76$ \\
\hline
\end{tabular}


Table 2. Parameter comparison of pre-test and post-test experimental group and control group

\begin{tabular}{|c|c|c|c|c|c|}
\hline \multirow[t]{2}{*}{ Variable Test } & \multirow[t]{2}{*}{ Group } & \multirow{2}{*}{$\begin{array}{l}\begin{array}{l}\text { Pre-test } \\
(n=11)\end{array} \\
\text { Mean } \pm S D\end{array}$} & \multirow{2}{*}{$\begin{array}{l}\text { Post-test }(n=11) \\
\text { Mean } \pm S D\end{array}$} & \multirow[t]{2}{*}{$\mathbf{t}$} & \multirow[t]{2}{*}{$\mathbf{p}$} \\
\hline & & & & & \\
\hline \multirow{3}{*}{$\begin{array}{l}\mathrm{VO}_{2} \mathrm{Max} \\
\text { Endurance }\end{array}$} & Plyometric with active recovery & $43.9 \pm 3.18$ & $50.6 \pm 2.02$ & -7.586 & 0.000 \\
\hline & Plyometric with passive recovery & $49.0 \pm 3.70$ & $51.9 \pm 2.89$ & -3.963 & 0.003 \\
\hline & Control group & $46.2 \pm 6.66$ & $45.7 \pm 6.16$ & 0.837 & 0.422 \\
\hline \multirow{3}{*}{$\begin{array}{l}\text { Left-hand grip } \\
\text { strength }\end{array}$} & Plyometric with active recovery & $39.8 \pm 3.24$ & $43.2 \pm 2.43$ & -6.983 & 0.000 \\
\hline & Plyometric with passive recovery & $40.5 \pm 3.55$ & $42.9 \pm 3.38$ & -5.157 & 0.000 \\
\hline & Control group & $40.3 \pm 3.79$ & $40.8 \pm 4.08$ & -1.376 & 0.199 \\
\hline \multirow{3}{*}{$\begin{array}{l}\text { Right-hand grip } \\
\text { strength }\end{array}$} & Plyometric with active recovery & $42.3 \pm 4.51$ & $46.2 \pm 5.25$ & -3.793 & 0.004 \\
\hline & Plyometric with passive recovery & $41.1 \pm 4.97$ & $45.9 \pm 5.45$ & -8.820 & 0.000 \\
\hline & Control group & $41.5 \pm 4.54$ & $46.8 \pm 6.08$ & -4.537 & 0.001 \\
\hline \multirow{3}{*}{ Flexibility } & Plyometric with active recovery & $17.5 \pm 3.18$ & $22.6 \pm 4.41$ & -5.916 & 0.000 \\
\hline & Plyometric with passive recovery & $21.3 \pm 4.03$ & $23.4 \pm 4.60$ & -3.266 & 0.008 \\
\hline & Control group & $21.7 \pm 3.88$ & $21.3 \pm 3.52$ & 0.793 & 0.446 \\
\hline \multirow{3}{*}{ Speed } & Plyometric with active recovery & $4.59 \pm 0.31$ & $4.32 \pm 0.43$ & 4.441 & 0.001 \\
\hline & Plyometric with passive recovery & $4.84 \pm 0.61$ & $4.47 \pm 0.47$ & 4.509 & 0.001 \\
\hline & Control group & $4.68 \pm 0.36$ & $4.71 \pm 0.31$ & -0.359 & 0.727 \\
\hline \multirow{3}{*}{ Leg power } & Plyometric with active recovery & $71.1 \pm 9.45$ & $79.3 \pm 15.7$ & -2.946 & 0.015 \\
\hline & Plyometric with passive recovery & $78.8 \pm 13.9$ & $84.8 \pm 15.5$ & -3.854 & 0.003 \\
\hline & Control group & $56.5 \pm 8.61$ & $57.1 \pm 9.57$ & -0.715 & 0.491 \\
\hline
\end{tabular}

Table 3. Parameters of difference in post-test results of the experimental group and control group

\begin{tabular}{|c|c|c|c|c|}
\hline Variable Test & Group & Mean \pm SD & $\mathbf{F}$ & $\mathbf{p}$ \\
\hline \multirow{3}{*}{$\mathrm{VO}_{2} \mathrm{Max}$ Endurance } & Plyometric with active recovery & $50.6 \pm 2.02$ & & \\
\hline & Plyometric with passive recovery & $51.9 \pm 2.89$ & 6.888 & 0.003 \\
\hline & Control group & $45.7 \pm 6.16$ & & \\
\hline \multirow{3}{*}{$\begin{array}{l}\text { Left-hand grip } \\
\text { strength }\end{array}$} & Plyometric with active recovery & $43.2 \pm 3.38$ & & \\
\hline & Plyometric with passive recovery & $42.9 \pm 3.38$ & 1.690 & 0.202 \\
\hline & Control group & $40.8 \pm 4.08$ & & \\
\hline \multirow{3}{*}{$\begin{array}{l}\text { Right-hand grip } \\
\text { strength }\end{array}$} & Plyometric with active recovery & $46.2 \pm 5.25$ & & \\
\hline & Plyometric with passive recovery & $45.9 \pm 5.45$ & 0.072 & 0.931 \\
\hline & Control group & $46.8 \pm 6.08$ & & \\
\hline \multirow{3}{*}{ Flexibility } & Plyometric with active recovery & $22.6 \pm 4.41$ & & \\
\hline & Plyometric with passive recovery & $23.4 \pm 4.60$ & 0.707 & 0.501 \\
\hline & Control group & $21.3 \pm 3.52$ & & \\
\hline \multirow{3}{*}{ Speed } & Plyometric with active recovery & $4.32 \pm 0.43$ & & \\
\hline & Plyometric with passive recovery & $4.47 \pm 0.47$ & 2.466 & 0.102 \\
\hline & Control group & $4.71 \pm 0.31$ & & \\
\hline \multirow{3}{*}{ Leg power } & Plyometric with active recovery & $79.3 \pm 15.7$ & & \\
\hline & Plyometric with passive recovery & $84.8 \pm 15.5$ & 12.145 & 0.000 \\
\hline & Control group & $57.1 \pm 9.57$ & & \\
\hline
\end{tabular}


are not significant, the effect $(\mathrm{p}>0.05)$ is found on the lefthand grip strength, right-hand grip strength, flexibility, and speed.

\section{Discussion}

This study was designed through a quasi-experimental design approach which was carried out in a controlled manner. To obtain the best results, the purpose of this study was to examine differences in the effect of $\mathrm{VO}_{2} \mathrm{Max}$ endurance, left and right-hand grip strength, flexibility, speed, and leg power of male judo athletes before and after being treated for eight weeks between the plyometric with active recovery (PAR), plyometric with passive recovery (PPR), and control group (GC).

The findings of this study confirm that treatment in the experimental group of plyometric with active recovery (PAR) and plyometric with passive recovery (PPR) resulted in a significant change effect on VO2Max endurance, left and right-hand grip strength, flexibility, speed, and leg power. Meanwhile, the control group (GC) only compared a significant increase in the right-hand grip test results. The findings of this study support the conclusions of previous literature that there is a significant relationship between speed and VO2Max endurance in aerobic and anaerobic energy systems to maximize judo athlete performance and adaptation to fatigue levels [23]. Furthermore, the findings carried out [24, 25] concluded, speed and leg power contribute to movement transfer techniques, fast throws, and handgrip strength; flexibility is needed to regulate an opponent's reach and distance.

This study conducted Çelik and Soyal [26] concluded that strength training carried out for six weeks caused significant handgrip strength and creatine kinase changes in judo athletes, and these changes came from duration scope, frequency, and severity training content. In addition, high-intensity judo training affects changes in heart rate, flexibility, and strength of the neck muscles, and adequate rest after exercise can help prevent injuries to judo athletes [11]. In addition, the findings of this study further confirm that there is a significant difference between the effect of plyometric training with active recovery (PAR), plyometric with passive recovery (PPR), and control group (GC) on $\mathrm{VO}_{2 \mathrm{Max}}$ endurance change and leg power. Meanwhile, there were no significant differences in handgrip strength, flexibility, and speed.

This study results conducted Péter-Zsolt Szabó et al. [27] concluded that repetition speed does not significantly affect the judo training period, and speed is not the main determining factor in judo training. The findings study Logeswaran [28] concluded, strength training carried out for eight weeks resulted in significant changes in the leg power of judo athletes. Furthermore, Franchini et al. [29] concluded that the aerobic fitness profile is essential as a basis for maximal oxygen absorption $\left(\mathrm{VO}_{2 \mathrm{Max}}\right)$, good recovery during rest periods, and is relevant to the performance of judo athletes. In addition, recovery can be an effective method in improving the performance of the physical condition of judo athletes, and the post-exercise recovery method currently widely used in judo training is using passive recovery with relaxation techniques that aim to relax muscle tension after exercise [30]. The findings of another study conducted Lesmana et al. [31] concluded that active recovery carried out by reducing $20 \%$ to $<50 \%$ DNM using the walking or jogging method after highintensity exercise will keep the hormone epinephrine secreted. The hormone epinephrine has a function as a guard for the heart muscle to keep contracting (systole) and not to suddenly decrease the heart's performance. In addition, active recovery by jogging for 10 minutes after doing anaerobic exercise will reduce $31.7 \%$ of lactic acid levels in the blood [32].

\section{Conclusions}

Based on the results of an analysis that has been carried out, it can be concluded that the ability of $\mathrm{VO}_{2} \mathrm{Max}$ endurance, handgrip strength, flexibility, speed, and leg power of judoka men experienced significant changes after being treated for eight weeks. Furthermore, the different test parameters confirmed that the experimental group was given the treatment, and the control group produced a significant difference in $\mathrm{VO}_{2} \mathrm{Max}$ endurance and leg power. In comparison, no significant differences occur in handgrip strength, flexibility, and speed. Furthermore, the results of this study are expected to be a reference or reference for coaches to be able to design, implement, and develop plyometric training programs, as well as pay attention to the post-exercise recovery process both in active and passive forms that can affect the performance of judo athletes' physical abilities, and gain performance - maximum during the match.

\section{Acknowledgments}

The researcher would like to thank all the reviewers who have always provided input so that this research can be published.

\section{Supporting Agencies}

The authors report no funding agencies.

\section{Disclosure Statement}

The authors declare no conflict of interest. 


\section{References}

1. Tavares Junior AC, Drigo AJ. Application of training periodization models by elite judo coaches. Arch Budo, 2017;13:139-46.

2. Los Arcos A, Mendez-Villanueva A, Martínez-Santos R. In-season training periodization of professional soccer players. Biol Sport. 2017;34(2):149- 55. https://doi.org/10.5114/biolsport.2017.64588

3. James LP, Kelly VG, Beckman EM. Periodization for mixed martial arts. Strength Cond J. 2013;35(6):34- 45. https://doi.org/10.1519/SSC.0000000000000017

4. Issurin VB. Benefits and Limitations of Block Periodized Training Approaches to Athletes' Preparation: A Review. Sport Med. 2016;46(3):329- 38. https://doi.org/10.1007/s40279-015-0425-5

5. Bompa T, Buzzichelli C. Periodization Training for Sports. Edition 3. United States of America: Human Kinetics; 2015.

6. AK R. Effects of judo specific complex training program on selected motor components among intercollegiate level judokas. Int J Yogic, Hum Mov Sport Sci 2019. 2019;4(1):259-63.

7. OuerguiI,ArdigòLP,SelmiO,LevittDE,ChtourouH,Bouassida A, et al. Changes in Perceived Exertion, Well-Being, and Recovery During Specific Judo Training: Impact of Training Period and Exercise Modality. Front Physiol. 2020;11:1- 10. https://doi.org/10.3389/fphys.2020.00931

8. Malovic P, Bjelica D, Atanasov D, Trivic T, Drapsin M, Trajkovic N, et al. Knee strength ratios in male judokas: Agerelated differences. Arch Budo. 2020;16:43-52.

9. Uzun A, Karakoc O. The Effects of Ten Weekly Plyometric Training of Judokas on Anaerobic Power. JETS, 2017;5:52. https://doi.org/10.11114/jets.v5i13.2902

10.Harris DM, Foulds S, Latella C. Evidencebased training recommendations for the elite judoka. Strength Cond J. 2019;41(2):108-18. https://doi.org/10.1519/SSC.0000000000000426

11.Ishikawa Y, Anata K, Hayashi H, Uchimura N, Okada S. Influence of fatigue on head angular acceleratioin judo highintensity exercise. Arch Budo. 2020;16:99-106.

12.Bompa TO, Buzzichelli CA. Peridization: Theory and Methodology of Training. Edition 6. United States of America: Human Kinetics; 2019.

13.Elshazly A, Khorshid H, Hanna H, Ali A. Effect of exercise training on heart rate recovery in patients post anterior myocardial infarction. Egypt Hear J, 2018;70(4):283-5. https://doi.org/10.1016/j.ehj.2018.04.007

14.Halson SL. Monitoring Training Load to Understand Fatigue in Athletes. Sport Med. 2014;44:139-47. https://doi.org/10.1007/s40279-014-0253-z

15.Foresti YF, Bertucci DR, de Carvalho CD, Kalva-Filho CA, de Andrade VL, Barbieri RA, et al. Comparison between special judo fitness test, metabolic variables and energy contribution in young judo athletes. Arch Budo. 2020;16:227-34.

16.Andriana LM, Ashadi K. Comparison of two types of exercise in the morning and evening on sleep quality. J Sport J Penelit Pembelajaran, 2019;5:98. https://doi.org/10.29407/js_unpgri.v5i1.12800

17. Yamagishi. Role of active and passive recovery in adaptations to high intensity training. 2015.

18.Luebbers PE, Hulver MW, Thyfault JP, Carper MJ, Lockwood RH, Potteiger JA. Effects of Plyometric Training and Recovery on Vertical Jump Performance and Anaerobic Power. Med Sci Sport Exerc. 2003;35(Suppl 1): S273. https://doi.org/10.1097/00005768-200305001-01514

19.Drinkwater EJ, Lane T, Cannon J. Effect of an Acute Bout of Plyometric Exercise on Neuromuscular Fatigue and Recovery in Recreational Athletes. Journal of Strength and Conditioning Research, 2009;23:1181-6. https://doi.org/10.1519/JSC.0b013e31819b79aa

20. White H, Sabarwal S. Quasi-Experimental Design and Methods: Impact Evaluation 8. UNICEF Office of Research; 2014.

21.Bushman B. ACSM's Complete Guide to Fitness and Health. Second. ACSM's Complete Guide to Fitness and Health. United States of America: Human Kinetics; 2017.

22.Fukuda DH. Assessments for Sport and Athletic Performance. Human Kinetics; 2019. https://doi.org/10.5040/9781492595243

23. Garbouj H, Selmi MA, Haj Sassi R, Haj Yahmed M, Chamari $\mathrm{K}$, Chaouachi A. Do maximal aerobic power and blood lactate concentration affect Specific Judo Fitness Test performance in female judo athletes? Biol Sport. 2016;33(4):367-72. https://doi.org/10.5604/20831862.1221890

24.Arazi H, Noori M, Izadi M. Correlation of anthropometric and bio-motor attributes with Special Judo Fitness Test in senior male judokas. Ido Mov Cult. 2017;17(4):19-24.

25.Mohammed HHM, ChoiHJ.Effect of an 8-weekjudo course on muscular endurance, trunk flexibility, and explosive strength of male university students. Sport Mont. 2017;15(3):51-3. https://doi.org/10.26773/smj.2017.10.010

26.Çelik NM, Soyal M. Comparing the hand grip power and creatine kinase levels of U-17 judo national team athletes before and after a 6-week strength training. Pedagog Phys Cult Sport. 2020;24(4):163-8. https://doi.org/10.15561/26649837.2020.0402

27.Péter-Zsolt Szabó, Grosu EF, Pop IN, Andras A, Monea D, Botezan MM. Repetition Speed in the Context of Specific Physical Training Period for Judo Athletes. Studia UBB Educatio Artis Gymn, 2017;62:43-9. https://doi.org/10.24193/subbeag.62(1).04

28.Logeswaran AS. Effect of strength training program on selected physical Fitness components of adolescent Judo players. Bharathiar Natl J Phys Educ Exerc Sci. 2020;11(2):5-12.

29.Franchini E, Del Vecchio FB, Matsushigue KA, Artioli GG. Physiological profiles of elite judo athletes. Sport Med. 2011;41(2):147-66. https://doi.org/10.2165/11538580-000000000-00000

30.Sopian S, Purnamasari I. Pengaruh Latihan Relaksasi Otot dengan Metode Progresif dan Autogenik terhadap Pemulihan Atlet Judo. J Kepelatihan Olahraga. 2019;11(1):1-11. https://doi.org/10.17509/jko-upi.v11i1.16780

31.Lesmana HS, Padli P, Broto EP. Effect of Active and Passive Recovery in Relieve Symptoms of Delayed Onset Muscle Soreness (DOMS). JOSSAE, 2018;2:38. https://doi.org/10.26740/jossae.v2n2.p38-41

32.Šančić J, Scruton A, Prosoli R, Štefan L, Sporiš G, Madić $\mathrm{D}$, et al. Active recovery vs sodium bicarbonate: Impact on lactic acid removal following a specific judo effort. Arch Budo. 2017;13:315-22 


\section{Information about the authors:}

Candra Kurniawan; (Corresponding author); https://orcid.org/0000-0002-4870-7553; rajhencandra@students.unnes.ac.id; Postgraduate State University of Semarang; Semarang, Indonesia.

Hari Setijono; https://orcid.org/0000-0001-8305-4933; setijono.hari@yahoo.com; Department of Sport Science, State University of Surabaya; Surabaya, Indonesia.

Taufiq Hidayah; https://orcid.org/0000-0002-9732-9624; taufiqhidayah@mail.unnes.ac.id; Department of Sport Science, State University of Semarang; Semarang, Indonesia.

Hadi Hadi; https://orcid.org/0000-0002-4876-8292; hadi_pabbsi@mail.unnes.ac.id; Department of Sport Science, State University of Semarang; Semarang, Indonesia.

Sugiharto Sugiharto; https://orcid.org/0000-0002-2561-9921; sugiharto.ikor@mail.unnes.ac.id; Department of Sport Science, State University of Semarang; Semarang, Indonesia.

Cite this article as:

Kurniawan $\mathrm{C}$, Setijono $\mathrm{H}$, Hidayah $\mathrm{T}$, Hadi $\mathrm{H}$, Sugiharto $\mathrm{S}$. The effect plyometric training with active-passive recovery for 8 weeks on performance physical abilities male judo athletes. Pedagogy of Physical Culture and Sports, 2021;25(6):361-366. https://doi.org/10.15561/26649837.2021.0604

This is an Open Access article distributed under the terms of the Creative Commons Attribution License, which permits unrestricted use, distribution, and reproduction in any medium, provided the original work is properly cited (http://creativecommons.org/licenses/by/4.0/deed.en).

Received: 05.09.2021

Accepted: 20.10.2021; Published: 30.12.2021 